\title{
Restorasi lamun; studi transplantasi lamun Enhalus acaroides di perairan pantai Kastela, Kota Ternate
}

\section{(Seagrass restoration; study on seagrass transplantation Enhalus acaroides at Kastela coastal area, Ternate city)}

\author{
M. Ridwan Lessy ${ }^{1,2}$ dan Yunita Ramili ${ }^{1}$ \\ ${ }^{1}$ Program Studi Ilmu Kelautan, FPIK- Universitas Khairun, Ternate \\ ${ }^{2}$ Laboratorium Hidrooseanografi -FPIK Universitas Khairun, Ternate \\ email: mrlessy_8375@yahoo.com
}

\begin{abstract}
Seagrass ecosystems in Ternate City had been damaged by human activity. Therefore, this study aims to examine the best method for a transplant of seagrass. The third methods are Turf method, Peat Pot method and anchored spring method. Samples of seagrass which used as the donor were taken from nearby locations. Observation of the survival rate of seagrass transplants carried out for three months, while measurements of environmental parameters were done twice a month. The results showed that the environmental parameters in seagrass ecosystem were still support. From the three methods tested, spring anchored method produce survival rates were highest $(86.7 \%)$ followed by Peat Pot method (73.3\%) and the method Turf (33.3\%).
\end{abstract}

Keywords: Seagrass Ecosystem; Transplatation;Coastal Area; Ternate

\begin{abstract}
ABSTRAK
Ekosistem padang lamun di Pesisir Kota Ternate mulai mengalami kerusakan karena aktivitas manusia. Untuk itu penelitian ini bertujuan untuk menguji metode yang terbaik untuk melakukan transpalntasi lamun. Ketiga metode yang diuji adalah metode Turf, metode Peat Pot dan metode spring anchored. Sampel lamun yang digunakan sebagai donor diambil dari lokasi sekitarnya. Pengamatan tingkat kelangsungan hidup lamun transplantasi dilakukan selama tiga bulan sedangkan pengukuran parameter lingkungan dilakukan dua kali dalam sebulan. Hasil penelitian menunjukkan bahwa parameter lingkungan masih mendukung kehidupan lamun. Dari ketiga metode yang diuji, metode spring anchored menghasilkan tingkat kelangsungan hidup yang paling tinggi $(86,7 \%)$ kemudian disusul oleh metode Peat Pot $(73,3 \%)$ dan metode Turf $(33,3 \%)$.
\end{abstract}

Kata Kunci: Ekosistem Lamun; Transplantasi; Wilayah Pesisir; Ternate

\section{Pendahuluan}

Ekosistem padang lamun merupakan suatu ekosistem di wilayah pesisir yang sangat kompleks. Ekosistem ini memiliki fungsi dan manfaat yang sangat penting bagi ekosistem lainnya di wilayah pesisir. Menurut Zieman, (1975) dalam Kuriandewa (1998), produktifitas ekosistem lamun dapat mencapai 1300 sampai dengan 3000 gr berat kering $/ \mathrm{m}^{2} /$ tahun. 
Di wilayah pesisir Kota Ternate, ekosistem padang lamun sebagian besar tersebar di bagian timur dan selatan wilayah pulau Ternate. Penyebarannya dimulai dari kelurahan sangaji, keluarahan kasturian, kelurahan salero, kelurahan muhajirin, kelurahan mangga dua hingga keluarahan kastela dan rua. Hal ini dikarenakan, wilayah pesisir timur dan selatan pulau Ternate memiliki dinamika perairan yang cukup tenang dengan substrat yang mendukung untuk pertumbuhan lamun. Beberapa spesies lamun yang ditemukan di wilayah pesisir Kota Ternate antara lain; Enhalus acoroides, Thalassia hemprichii, Cymodocea rotundata dan Halophilla ovalis (Rano, 2011). Diantara jenis-jenis tersebut, Enhalus acariodes merupakan jenis sangat melimpah (Husein, 2001). Namun dilain sisi, ekosistem padang lamun sangat rentan terhadap kerusakan yang ditimbulkan akibat kegiatan pemanfaatan wilayah pesisir baik secara langsung maupun tidak langsung. Untuk itu, perlu ada usaha untuk konservasi terhadap ekosistem lamun di Kota Ternate. Salah satu upaya dalam melakukan konservasi lamun adalah dengan melakukan restorasi yang salah satunya dengan metoda transplantasi (penanaman) lamun. Beberapa metoda transplantasi lamun telah dikembangkan dan diujicoba di dalam maupun di luar negeri (Lanuru $d k k, 2013$; Wutthivorawong et all, 2014). Namun demikian, kegiatan transplantasi lamun belum pernah dilakukan di wilayah pesisir pantai Kota Ternate, sehingga penelitian ini diharapkan memberikan data dan informasi berupa tingkat kelangsungan hidup lamun dan metoda transplantasi lamun Enhalus acoroides yang terbaik dan cocok untuk diaplikasi di wilayah kajian dalam upaya restorasi ekosistem lamun di pesisir Kota Ternate.

Lamun jenis Enhalus acaroides terpilih sebagai sampel dalam penelitian ini dikarenakan lamun jenis ini merupakan jenis lamun yang penyebarannya merata di semua wilayah pesisir pantai Kota Ternate. Selain itu, lamun ini memiliki jenis tegakkan yang tinggi dan memiliki perakaran yang kuat dan jenis lamun ini juga mudah untuk disampling.

\section{Metode Penelitian}

\subsection{Waktu dan Tempat Penelitian}

Penelitian ini direncanakan berlangsung selama tiga bulan dari bulan September hingga November 2015. Lokasi penelitian untuk pengambilan sampel dan transplantasi akan dilakukan di perairan pantai Kastela, Kota Ternate. Lokasi penelitian dibagi menjadi dua titik pengamatan. (Gambar 1).

\subsection{Bahan dan Data}

\subsubsection{Metode Tranpslantasi}

Penelitian ini merupakan penelitian eksperimental lapangan. Dimana desain perlakuan transplantasi lamun Enhalus acaroides dibagi menjadi tiga metode yakni; Metoda turf (Short and Coles, 2001), merupakan metoda transplantasi dengan cara mengambil lamun dengan menggunakan sekop beserta sedimen dan rizomanya lalu ditanam di lokasi transplantasi.

Metoda plugs yang dimodifikasi dengan teknik peat pot (Calumpong and Fonseca, 2001), Metoda ini hampir mirip dengan mentoda turf, akan tetapi pemindahan lamun berserta akarnya dengan menggunakan core yang bisa terbut dari pipa PVC berdiameter 4-6 mm. plug kemudian ditanamn di lokasi transplantasi. Namun dalam penelitian ini, metoda ini akan dimodifikasi dengan menggunakan peat pot atau wadah yang terbuat dari plastik. Dimana sampel lamun yang telah diambil dengan core akan dimasukan 
dalam pot yang kemudian dibenamkan dalam lubang yang telah digali sebelumnya di lokasi transplantasi.

Metoda Spring anchored (Azkab, 1999), merupakan metoda transplantasi dimana bibit tanaman lamun diambil tanpa substrat dengan menggunakan pisau dan kemudian ditransplantasikan di lokasi yang baru. Bibit tanaman dikaitkan pada jangkat kemudian dimasukan kedalam substrat yang telah digali sebelumnya. Pada penelitian ini, jangkar akan dibuat dari besi berdiameter $12 \mathrm{~mm}$. Besi jangkar akan akan dibuat menjadi bingkai berbentuk bujur sangkar dengan ukuran $0,5 \times 0,5 \mathrm{~m}$ yang dibagi menjadi 25 grid berukuran $10 \times 10 \mathrm{~cm}$. Bingkai yang akan dibuat sebanyak tiga unit.

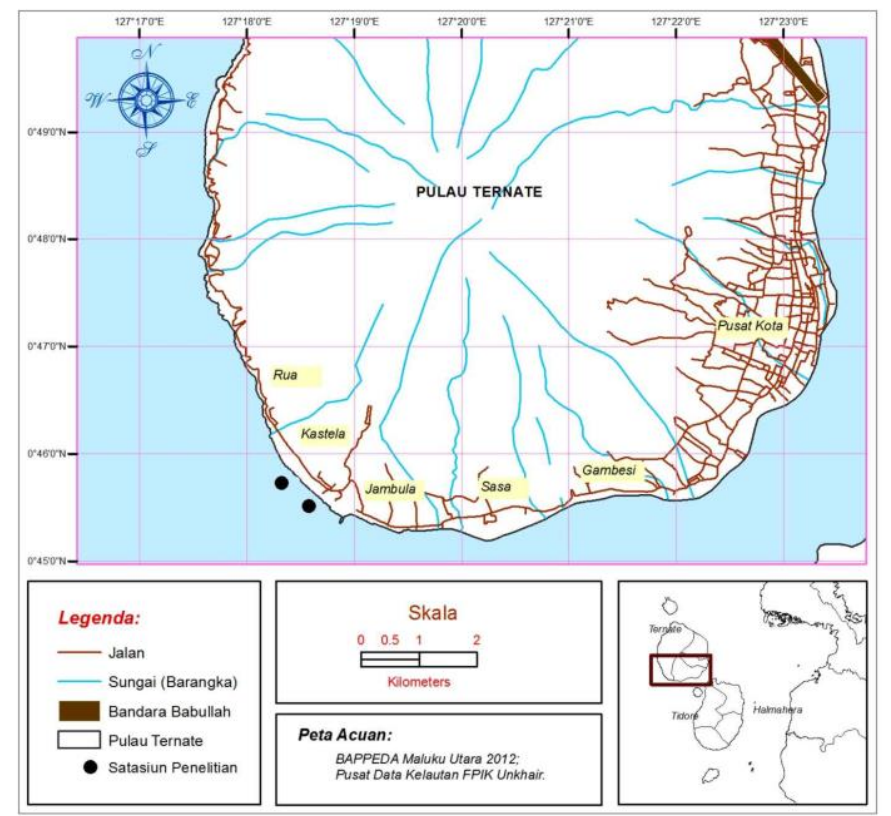

Gambar 1. Peta Lokasi Penelitian

\subsubsection{Metoda Pengumpulan Data}

Pemilihan sampel lamun Enhalus acoroides dilakukan secara purposive random sampling. Sampel lamun Enhalus acoroides yang akan diambil sebanyak 15 tegakan untuk setiap metoda transplantasi yang digunakan. Selanjutnya lamun akan ditransplant kembali pada kedalaman $1-2$ m sesuai dengan kedalaman lamun donor. Pengamatan tingkat kelangsungan hidup lamun yang di transplantasi akan dilakukan setiap dua minggu sekali selama tiga bulan. Selanjutnya tingkat kelangsungan hidup lamun yang ditransplantasi dihitung sebagai persentase lamun yang masih hidup sampai dengan akhir waktu penelitian.

Pengukuran parameter lingkungan dilakukan bersamaan dengan pengamatan tingkat kelangsungan hidup lamun yang ditransplantasi yaitu setiap bulan selama tiga bulan. Parameter oseanografi yang diukur adalah suhu, salinitas, oksigen terlarut, kekeruhan, derajat keasaman $(\mathrm{pH})$, dan kecepatan arus. Peralatan yang digunakan untuk mengukur parameter tersebut adalah thermometer untuk mengukur suhu, refraktometer untuk mengukur salinitas, $\mathrm{pH}$ meter untuk mengukur $\mathrm{pH}$, oksigen terlarut dan kekeruhan diukur dengan Horiba water quality checker, sedangkan untuk pengeukuran kecepatan arus menggunakan flow meter. 


\subsubsection{Analisis Data}

Perhitungan tingkat kelangsungan hidup lamun Enhalus acoroides yang ditransplantasi dengan menggunakan persamaan;

$$
\mathrm{SR}=\frac{N t}{N o} x 100 \%
$$

Dimana:

$\mathrm{SR}=$ Tingkat kelangsungan hidup $(\%)$

$N t=$ Jumlah tegakan lamun yang masih hidup hingga akhir waktu penelitian

No = Jumlah tegakan lamun yang ditransplantasikan pada awal penelitian

Sementara, untuk penentuan metoda transplantasi yang cocok, data tingkat kelangsungan hidup yang diperoleh akan diolah dengan menggunakan ANOVA (analysis of variance) satu arah. Jika hasil uji ANOVA menjukkan ada perbedaan yang signifikan, maka Tukey's Post Hoc Test akan digunakan untuk menentukan dimana perbedaan itu berada. Semua proses pergitungan dilakukan dengan bantuan Software SPSS versi 17.

\section{Hasil dan Pembahasan}

Hasil pengukuran beberapa parameter lingkungan perairan yang memengaruhi pertumbuhan dan kelangsungan hidup lamun disajikan pada Tabel 1. Kedalaman air dilokasi transplantasi pada saat surut berkisar antara $0.5 \mathrm{~m}-1 \mathrm{~m}$ sedangkan pada saat pasang sekitar $1.5-2.5 \mathrm{~m}$. Kedalaman perairan tersebut merupakan kedalaman perairan yang ideal untuk melakukan transplantasi lamun. Hal ini seperti yang direkomendasikan oleh Davis (1999) bahwa kedalaman yang baik untuk transplpantasi lamun adalah $0,5 \mathrm{~m}-1,5 \mathrm{~m}$ pada saat surut karena pada kedalaman tersebut lokasi masih tertutupi oleh air pada saat surut dan intesitas cahaya masih relatif tinggi tiba di dasar perairan.

Secara umum suhu permukaan tampak lebih tinggi di siang hari dibandingkan dengan malam hari. Hal ini dikarenakan penyinaran matahari di siang hari menyebabkan air laut menyerap banyak panas sehingga suhu air naik. Namun demikian hasil pengukuran suhu masih dibawah baku mutu yang ditetapkan dalam Peraturan Menteri Negara Lingkungan Hidup No 51 tahun 2004 tentang baku mutu air laut untuk kehidupan boita. Dengan demikian nilai suhu yang terukur menunjukkan bahwa suhu di lokasi penelitian masih mendukung untuk kehidupan lamun. Secara umum lamun menghendaki suhu yang berkisar antara $20{ }^{\circ} \mathrm{C}-30{ }^{\circ} \mathrm{C}$, dengan optimum untuk fotosintesis pada kisaran $28{ }^{\circ} \mathrm{C}-30{ }^{\circ} \mathrm{C}$ (Merryanto, 2000).

Tabel 1. Data Primer Kualitas Perairan pada Lokasi Penelitian

\begin{tabular}{|c|c|c|c|c|c|c|}
\hline Parameter & Baku Mutu*) & Sept & Okt & Nov & Range & Rata-Rata \\
\hline Suhu (oC) & Alami & 25.6 & 25.5 & 25.6 & $25.5-25.6$ & 25.57 \\
\hline salinitas (\%o) & Alami & 33.1 & 33.3 & 32.7 & $32.7-33.3$ & 33.03 \\
\hline $\mathrm{pH}$ & $6.5-8.5$ & 7.97 & 7.17 & 7.74 & $7.17-7.97$ & 7.63 \\
\hline $\mathrm{DO}(\mathrm{mg} / \mathrm{l})$ & $>5$ & 5.63 & 5.64 & 5.5 & $5.5-5.64$ & 5.59 \\
\hline Kekeruhan (NTU) & 5 & 1.23 & 1.21 & 1.23 & $1.21-1.23$ & 1.22 \\
\hline $\operatorname{Arus}(\mathrm{m} / \mathrm{det})$ & & 0.3 & 0.25 & 0.3 & $0.25-0.3$ & 0.28 \\
\hline
\end{tabular}


Sama halnya dengan suhu, hasil pengukuran salinitas pada penelitian ini mendapatkan nilai kisaran antara 32.7 \%o - 33.3\%o dengan rerata $33.03 \%$. Nilai salinitas ini masih dibawah nialai ambang batas yang ditetapkan dalam Permen LH No 51 tahun 2004 sehingga masih mendukung untuk pertumbuhan lamun. Kisaran salinitas ini banyak dipengaruhi oleh perubahan suhu permukaan dan pola arus yang berkembang di perairan lokasi studi. Pergerakan arus pasang surut yang terbentuk di lokasi studi akan bergantian membawa massa air masuk dan keluar ke perairan lepas, sehingga salinitas juga akan terpengaruh.

Derajat keasaman $(\mathrm{pH})$ merupakan ukuran tentang nilai kosentrasi ion hidrogen sehingga menunjukkan apakah larutan itu bersifat asam atau basa dalam reaksinya. Derajat keasaman $(\mathrm{pH})$ mempunyai pengaruh yang sangat besar terhadap organisme perairan sehingga dipergunakan sebagai petunjuk untuk menyatakan baik buruknya suatu perairan. Menurut Nybakken (1992), kisaran pH yang optimal untuk air laut antara 7,5-8,5. Kisaran $\mathrm{pH}$ yang baik untuk lamun ialah pada saat $\mathrm{pH}$ air laut 7,5-8,5 , karena pada saat kondisi $\mathrm{pH}$ berada dikisaran tersebut maka ion bikarbonat yang dibutuhkan oleh lamun untuk fotosintesis dalam keadaan melimpah (Phillip dan Menez, 1988). Hasil penelitian ini mendapatkan nilai kisaran $\mathrm{pH}$ antara 7,17 - 7,97 dengan nilai rerata 7,63. Nilai tersebut masih memungkinkan untuk kehidupan organisme laut dan merupakan kisaran optimum untuk pertumbuhan lamun.

Oksigen terlarut (DO) dan kekeruhan pada lokasi penelitian masih mendukung pertumbuhan lamun. Hasil pengukuran oksigen terlarut memperlihatkan nilai kisaran antara 5,5 mg/l - 5,64 mg/l dengan nilai rata-rata 5,59 mg/l. Nilai tersebut masih sesuai dengan nilai baku mutu lingkungan untuk kehidupan biota laut. Begitu pula dengan hasil penelitian ini memperoleh kisaran nilai kekeruhan antara 1,21 NTU - 1,23 NTU dengan nilai rereta 1,22 NTU.

Pengukuran kecepatan arus pada penelitian ini memperoleh kecepatan berkisar antara $0,25-0,3 \mathrm{~m} /$ det dengan nilai rata-rata $0,28 \mathrm{~m} /$ det. Nilai kecepatan arus ini masih mendukung untuk pertumbuhan lamun. Produktivitas padang lamun juga dipengaruhi oleh kecepatan arus perairan. Pada saat kecepatan arus sekitar 0,5 m/detik, jenis Thallassia testudium mempunyai kemampuan maksimal untuk tumbuh (Dahuri, 2004). Selain itu, berdasarkan hasil pengukuran arus, menunjukkan bahwa perairan lokasi transplantasi merupakan perairan yang tenang pada saat surut karena terdapat karang penghalang di bagian luar pantai.

Tingkat kelangsungan hidup lamun Enhalus acoroides yang di transpalntasi di lokasi studi memperlihatkan bahwa terjadi penurunan kelangsungan hidup lamun transplantasi dengan ketiga metode tersebut (gambar 2). Pada pengamatan ke-1, memperlihatkan bahwa semua lamun yang ditanam dengan ketiga metode tersebut masih dapat bertahan hidup (100\%). Namun selanjutnya pada pengamatan ke-2, telah terjadi penurunan kelangsungan hidup lamun Enhalus acoroides pada semua teknik transplantasi yang diujicobakan. Penurunan yang signifikan terjadi pada teknik transplantasi dengan metode turf dimana pada waktu pengamatan ke-3 jumlah persentase kelangsungan hidup sebesar 73,3\% namun turun menjadi 33,3\% pada waktu pengamatan ke-6. Sedangkan yang sedikit mengalami penurunan tingkat kelangsungan hidup adalah lamun dengan metode transplantasi spring anchored yakni dari $100 \%$ pada pengamatan ke-1 menjadi $86.7 \%$ pada pengamatah ke-6.

Nilai yang sama juga didapatkan Lanuru, et al., (2010) di Pulau Barranglompo pada transplantasi lamun E. acoroides selama dua bulan pengamatan (70\% - 88\%) dengan tiga metode transplantasi. Tingginya tingkat kelangsungan hidup lamun $E$. 
acoroides didukung oleh struktur akar yang besar dan kuat sehingga memungkinkan $E$. acoroides dapat bertahan hidup saat transplantasi dan meningkatkan kelangsungan hidupnya. Hal ini sesuai dengan pernyataan Tomascik, et al., (1997), bahwa E. acoroides memiliki akar mencapai panjang lebih dari $50 \mathrm{~cm}$ sehingga dapat menancap secara kuat pada substrat.

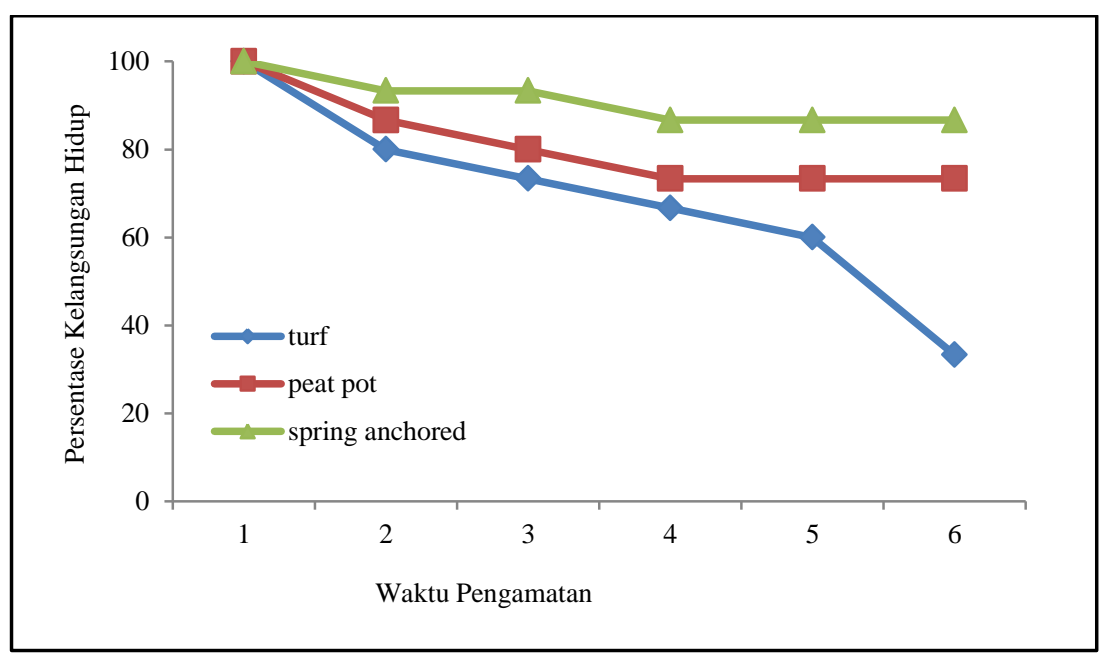

Gambar 2. Persentase Kelangsungan Hidup Lamun Enhalus acaroides yang ditransplantasi di Lokasi Studi

Penurunan persentase kelangsungan hidup lamun Enhalus acoroides yang ditransplantasi dengan ketiga metode tersebut di lokasi studi diakibatkan karena kematian lamun tersebut. Hasil pengamatan lapangan memperlihatkan bahwa umunya kematian lamun yang ditransplantasi dengan motode turf mengalami kematian karena tercabut/terlepas dari substrat tempat transplantasi karena gelombang yang cukup kuat. Sementara untuk metode peat pot, kematian lamun transplant diakibatkan karena beberapa terlepas dari substrat dan beberapa pot mengalami pengurangan subtsrat karena miring. Sedangkan dengan metode spring anchored, lamun yang di transplantasi mengalami kematian karena terlepas dari substrat.

Berdasarkan informasi masyarakat beberapa kali terjadi gelombang yang cukup tinggi.. Tingginya gelombang disebabkan karena pada saat penelitian terjadi peralihan musim yang menyebabkan angin kencang sehingga gelombang menjadi besar. Besarnya gelombang menyebabkan transplant yang baru ditanam mudah tercabut karena cengkraman akar terhadap substrat yang masih lemah. Lanuru $d k k$ (2013) mengatakan dalam penelitiannya bahwa musim peralihan dari musim tirnur ke musim barat biasanya terjadi pada bulan September dan Oktober. Pada musim tersebut kecepatan dan arah angin bervariasi dan dalam periode tertentu kecepatan angin sangat besar untuk membangkitkan gelombang dan arus yang kuat. Sehingga dapat menyebabkan material lamun yang ditransplantasi tercabut dari dasar. Hal inilah yang menjadi salah satu penyebab menurunnya tingkat keangsungan hidup pada jenis lamun yang baru di transplantasi.

Selanjutnya faktor lain yang kemungkinan dapat menyebabkan kegagalan dalam dalam penelitian ini adaalah aktivitas manusia. Lokasi penelitian merupakan perairan yang tenang dan tempat wisata sehingga sering terlihat anak-anak yang berenang dan 
nelayan yang menambatkan perahu. Aktivitas ini dapat memberikan dampak pada terlepasnya lamun dari substrat.

Untuk menguji tingkat kelangsungan hidup dari tiga metode transplantasi yang diujicoba maka dilakukan uji statistik menggunakan ANOVA. Hasil uji ANOVA disajikan pada Tabel 2. Hasil uji ANOVA menunjukkan bahwa tingkat kelangsungan hidup lamun yang ditransplantasi dengan metode turf, peat pot, dan spring anchored tidak berbeda nyata. Hasil ini menunjukkan bahwa meskipun metode spring anchored/Frame menghasilkan tingkat kelangsungan hidup yang lebih tinggi dari dua metode lainnya namun perbedaan tersebut tidak signifikan.

Tabel 2. Hasil Uji ANOVA Satu Arah

\begin{tabular}{lrrrrr}
\hline Source of Variation & \multicolumn{1}{c}{ SS } & df & \multicolumn{1}{c}{ MS } & F & Sig. \\
\hline Between Groups & 968.543 & 2 & 484.272 & 1.561 & .242 \\
Within Groups & 4653.937 & 15 & 310.262 & & \\
Total & 5622.480 & 17 & & & \\
\hline
\end{tabular}

Metode frame/spring anchored ini lebih cocok untuk perairan yang dalam (daerah subtidal) (Calumpong dan Fonseca, 2001). Bingkai besi dari metode frame/spring anchored menyediakan perlindungan awal bagi lamun yang ditransplantasi dari gangguan bioturbator (fauna penganggu) dan dari arus dan gelombang 'kuat yang dapat dapat merusak daun dan menyebabkan material lamun yang ditransplantasi tercabut dari dasar. Hal ini mungkin bisa menjelaskan mengapa tingkat kelangsungan hidup lamun yang ditransplantasi dengan metode spring anchored lebih tinggi dibandingkan dengan dua metode lainnya (turf dan peat pot). Salah satu kelemahan metode frame adalah biaya bahan dan pembuatannya relatif mahal (Lanuru, et al. 2010).

\section{Kesimpulan}

Lamun merupakan bagian dari ekosistem pesisir yang sangat penting. Untuk itu, dalam penelitina ini, mendapatkan bahwa tingkat kelangsungan hidup lamun $E$. Acoroides yang di transplantasi di lokasi studi mengalami penurunan akibat kondisi alam dan aktivitas manusia. Secara keseluruhan tidak ada perbedaan yang nyata antara ketiga metode tersebut namun metode spring anchored mendapatkan nilai kelangsungan hidup lamun transplantasi yang lebih baik. Serta,faktor lingkungan di lokasi studi masih mendukung untuk pertumbuhan lamun sehingga cocok untuk dilakukan transplantasi.

\section{Ucapan Terima Kasih}

Ucapan terima kasih disampaikan kepada Rektor Universitas Khairun, Ketua Lembaga Penelitian dan Pengabdian Masyarakat, Dekan Fakultas Perikanan dan Ilmu Kelautan, Kepala Laboratorium Hidrooseanografi dan Semua pihak yang telah membantu dalam menyelesaikan penelitian ini.

\section{Daftar Pustaka}

Azkab, M.H. 1999. Petunjuk Penanaman Lamun, Oseana XXIV (3): 11-25

Calumpong, $\mathrm{H}$ and Fonseca, M. Transplantation and Others Seagrass Restoration Method. In: Short,F.T., Coles, R.G. and Catherine,A.S. 2001. Global Seagrass Research Methods. Elsevier, Oxford., P 425-444. 
Dahuri, H.R. J. Rais,.S.S Ginting, dan M.J.Sitepu, 2004. Pengelolaan Sumberdaya Wilayah Pesisir dan Lautan secara Terpadu. Pustaka Teknologi dan Informasi. PT Pradnya Paramita, Jakarta

Husen, F. H.D. 2001, Struktur Komunitas Lamun pada perairan Pantai Kota Ternate. Skripsi tidak diterbitkan. Ternate. Fakultas Pertanian Universitas Khairun Ternate

Kuriandewa, T.E. 1988. Lamun di Teluk Ambon dan Permasalahnya. Seminar Pengenalan Pesisir Pulau Ambon.

Lanuru,M. Supriadi, dan Amri, K. Kondisi Oseanografi perairan Lokasi Transplantasi Lamun Enhalus acaroids Pulau Barrang Lompo, Kota Makassar. 2013. Jurnal Bahari. Vol. 7 No 1. Jan-apr ISSN. 0216-4841. P.65-76.

Nybakken, J.W. 1992. Biologi Laut. Suatu Pendekatan Ekologis. Terjemahan dari Marine Biology: An Ecological Approach. Alih Bahasa: M. Eidman, Koesoebiono, D.G. Bengen dan M. Hutomo. Gramedia. Jakarta. 459 hlm.

Phillips, C. Roland dan Menez, G.E. 1988. Seagrass. Smithsonian Institution Press. Washington D

Rano, R. 2011. Inventarisasi Vegatsi Lamun di Perairan Pantai Kasturian Kota Ternate. Laporan PKL. Fakultas Perikanan dan Ilmu Kelautan Universitas Khairun.

Short, F.T. and R.G. Coles. 2001. Global Seagrass Research Methods. Elsevier Science B.V., Amsterdam.

Tomascick, T., A.J. Mah, A. Nontji \& M.K. Kasim Moosa. 1997. The of Seagrass Biology: An Ecosystem Percepective. Garland STPM Press. Ziemen, J.C. 1980. Produktivity in Ecology of the Indonesia Seas. Part One. Periplus Edition (HK) Ltd., Singapore.

Wutthivorawong, C., Boonyanate,P., Polpool,S., and Suwannachote,K. Transplantation of Seagrass, Haludule pinifolia (MiKi) Den Hartog: Survival Between Mangrove and Urban Areas in Makampom Bay, Rayong Province, Thailand. 2014. 